Jurnal Kebidanan Mutiara Mahakam, Vol 8, No 1, Tahun 2020, Hal 8-20

ISSN : 2623-2553 (Online)

ISSN : 2549-0532 (Cetak)

\title{
HUBUNGAN PRENATAL YOGA DENGAN TINGKAT KECEMASAN DAN KUALITAS TIDUR PADA IBU HAMIL TRIMESTER III
}

\author{
Andra Destyan Gunawan ${ }^{1}$, Novia Fransiska Ngo $^{2}$, Nur Khoma Fatmawati ${ }^{3}$ \\ ${ }^{1}$ Program Studi Kedokteran, Fakultas Kedokteran, Universitas Mulawarman \\ ${ }^{2}$ Laboratorium Ilmu Kebidanan dan Kandungan, Fakultas Kedokteran, Universitas \\ Mulawarman \\ ${ }^{3}$ Laboratorium Ilmu Penyakit Mata, Fakultas Kedokteran, Universitas Mulawarman \\ Email:andra@andyp.id,novia_fn2002@yahoo.com,gusma_riqo@yahoo.com
}
Dikirim
: 10 Oktober 2019
Diterima
: 24 Oktober 2019
Diterbitkan
: 20 Maret 2020

\begin{abstract}
Quite a few women experienced anxiety and fear during pregnancy and nearing the labor process, while one of the effects of this situation can reduce sleep quality. One of the efforts that can be done to overcome these inconveniences is prenatal yoga. Based on preliminary studies, it was found that pregnant women who have been doing yoga experience a reduction of the complaints that they feel. This study aims to determine the relationship between prenatal yoga with anxiety level and sleep quality in third-trimester pregnant women. This research was observational research using pretest-posttest with control group design. This research samples were 32 respondents who were divided into 2 groups, which are the intervention group and control group. Data collection was carried out using a questionnaire to determine the level of anxiety and sleep quality of the respondents. Based on the bivariate results, there were differences of anxiety levels before and after prenatal yoga $(p$-value $=0.001)$, there were differences in sleep quality before and after prenatal yoga $(p$-value $=0,000)$, there was a relationship between prenatal yoga and anxiety levels ( $p$-value $=0,001$ ), and there was a relationship between prenatal yoga and sleep quality (p-value $=0,000)$. There were differences of anxiety level and quality of sleep before and after prenatal yoga. There was a relationship between prenatal yoga with anxiety levels and sleep quality. Pregnant women are expected to be able to exercise regularly like prenatal yoga, to reduce complaints during pregnancy such as anxiety and improve sleep quality.
\end{abstract}

Keywords: Prenatal Yoga, Anxiety Level, Sleep Quality, Third Trimester Pregnancy 
Jurnal Kebidanan Mutiara Mahakam, Vol 8, No 1, Tahun 2020, Hal 8-20

\section{PENDAHULUAN}

Kehamilan dan persalinan merupakan proses yang alami dan menimbulkan rasa sakit. Banyak wanita yang merasakan rasa sakit tersebut melebihi dari yang seharusnya karena dipengaruhi oleh rasa panik dan stres. Hal ini disebut fear-tension-pain concept (takut - tegang - sakit), rasa takut dapat menimbulkan ketegangan atau kepanikan yang dapat menyebabkan otot menjadi kaku dan akhirnya menyebabkan rasa sakit (Larasati \& Wibowo, 2012). Rasa panik dan takut merupakan gejala dari kecemasan (Annisa \& Ifdil, 2016). Pada ibu bersalin kecemasan dapat menginduksi ketegangan otot sirkuler pada bagian bawah uterus atau kekakuan serviks dan hipoksia uterus, yang akan menimbulkan rasa nyeri. Selain itu juga terdapat hubungan antara tingkat kecemasan dengan lama partus kala I pada primigravida (Difarissa, dkk., 2016). Pada ibu, partus lama dapat menyebabkan infeksi, kehabisan tenaga, dehidrasi, kadang juga dapat terjadi perdarahan postpartum yang dapat menyebabkan kematian, sedangkan pada janin dapat terjadi infeksi, cedera dan asfiksia yang dapat meningkatkan kematian bayi (Wahyuningsih, 2010).

Menurut ADAA (Anxiety and Depression Association of America) sekitar 52\% wanita dilaporkan mengalami peningkatan kecemasan atau depresi saat hamil (ADAA, 2015). Pada tahun 2016, pernah dilakukan sebuah penelitian di Puskesmas Samarinda dan didapatkan hasil bahwa dari 40 responden yang terlibat pada penelitian tersebut seluruhnya mengalami kecemasan dengan berbagai tingkatan mulai dari kecemasan tingkat ringan hingga sangat berat (Sarifah, 2016).

Efek lain dari kecemasan adalah mengganggu tidur, dikarenakan kecemasan dapat meningkatkan kadar norepinefrin dalam darah melalui sistem saraf simpatis. Perubahan kimia ini menyebabkan kurangnya waktu tidur tahap III NREM dan tidur REM, dan lebih sering terbangun (Komalasari, dkk., 2012). Sebuah penelitian pernah dilakukan di Puskesmas Lampung pada tahun 2015, menunjukkan adanya hubungan yang signifikan antara tingkat kecemasan dengan kualitas tidur pada ibu hamil primigravida trimester III. Didapatkan hasil bahwa dari 35 ibu hamil, sekitar 65,7\% menunjukkan tingkat kecemasan sedang sampai berat dan sekitar 68,6\% menunjukkan kualitas tidur buruk (Robin, 2015).

Menurut sebuah survei yang dilakukan di Amerika mengatakan bahwa sekitar 78\% dari ibu hamil mengeluh tidak nyenyak tidur (National Sleep Foundation, 2006). Sekitar $25 \%$ dari ibu hamil mengeluhkan gangguan tidur pada trimester pertama dan meningkat menjadi hampir 75\% ketika memasuki trimester ketiga (Jamalzehi, dkk., 2017). 
Upaya yang dapat dilakukan untuk mengatasi gangguan - gangguan tersebut adalah dengan senam yoga (Pratignyo, 2014). Dalam gerakan senam yoga terkandung efek relaksasi yang dapat menstabilkan emosi ibu hamil, sebab gerakan yoga memfokuskan perhatian pada ritme napas, mengutamakan kenyamanan serta keamanan dalam berlatih (Krisnadi, 2010). Dari studi pendahuluan yang dilakukan di Rumah Sakit Amalia Bontang yang merupakan satu - satunya rumah sakit di Bontang yang memiliki fasilitas prental yoga, hampir seluruh ibu hamil yang mengikuti prenatal yoga mengalami pengurangan dari keluhan - keluhan yang mereka rasakan.

Berdasarkan latar belakang di atas peneliti tertarik untuk melakukan penelitian tentang "Hubungan Prenatal Yoga dengan Tingkat Kecemasan dan Kualitas Tidur pada Ibu Hamil Trimester III".

\section{METODE PENELITIAN}

Metode yang digunakan pada penelitian ini adalah observasional dengan desain pretest - posttest with control group. Penelitian ini mengambil lokasi di Rumah Sakit Amalia Bontang dan dilaksanakan pada bulan Mei 2019 hingga September 2019.

Populasi pada penelitian ini adalah ibu hamil yang melakukan kunjungan ke Rumah Sakit Amalia Bontang. Pada penelitian ini cara pengambilan sampel dilakukan dengan menggunakan teknik purposive sampling. Sampel pada penelitian ini berjumlah 32 responden yang diambil sesuai dengan kriteria inklusi dan eksklusi yang sudah ditentukan. Kriteria inklusi kelompok intervensi dan kontrol:

1. Bersedia menjadi responden.

2. Kehamilan tunggal.

3. Memiliki usia kehamilan lebih dari 28 minggu.

Kriteria eksklusi kelompok intervensi:

1. Pernah mengikuti prenatal yoga sebelumnya.

2. Memiliki pantangan atau kontraindikasi untuk mengikuti prenatal yoga.

Kriteria eksklusi kelompok kontrol:

1. Memiliki gangguan pada kehamilan.

Data yang digunakan merupakan data primer berupa tingkat kecemasan dan kualitas tidur responden yang didapatkan melalui pengisian kuesioner. Hasil penelitian disajikan dengan menggunakan analisis univariat dan bivariat. Analisis univariat dilakukan dengan memasukkan data secara terpisah dalam tabel distribusi frekuensi. Analisis bivariat dilakukkan untuk melihat hubungan antar variabel bebas dengan 
Jurnal Kebidanan Mutiara Mahakam, Vol 8, No 1, Tahun 2020, Hal 8-20

variabel terikat. Uji yang digunakan adalah uji Wilcoxon dengan nilai kepercayaan $\mathrm{P}<$ 0,05 untuk melihat perbedaan tingkat kecemasan dan kualitas tidur antara sebelum dan sesudah prenatal yoga, dan uji Chi-Square dengan nilai kepercayaan $\mathrm{P}<0,05$ untuk melihat hubungan prenatal yoga dengan tingkat kecemasan dan kualitas tidur.

Pengelolahan data dilakukan dengan menggunakan program komputer pengolah angka dan statistik. Penyajian data dilakukan dalam bentuk narasi, tabel dan grafik.

\section{HASIL DAN PEMBAHASAN}

Data pada penelitian ini didapatkan dari ibu hamil yang secara sukarela menjadi responden. Responden yang didapatkan pada penelitian ini sebanyak 32 ibu hamil, yang dibagi menjadi 2 kelompok yaitu 16 orang pada kelompok intervensi dan 16 orang pada kelompok kontrol.

\section{Distribusi Responden Berdasarkan Usia}

Jumlah responden terbanyak untuk kelompok intervensi dan kelompok kontrol adalah berusia 25 - 30 tahun dengan jumlah masing - masing sebanyak $9(56,3 \%)$ dan 10 $(62,5 \%)$ ibu hamil.

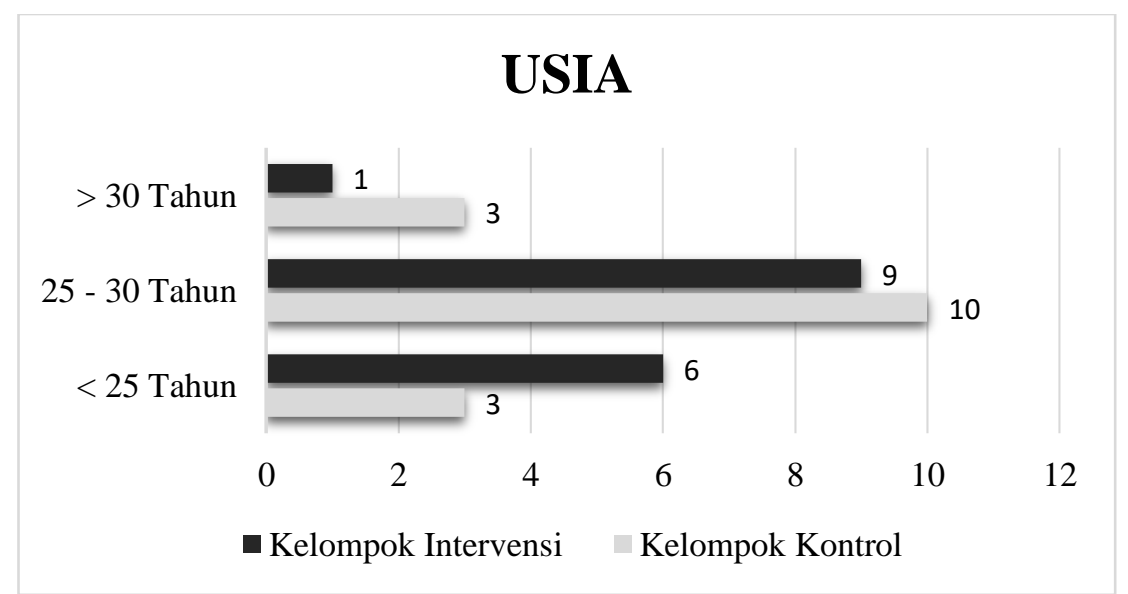

Gambar 1. Distribusi Responden Berdasarkan Usia

\section{Distribusi Responden Berdasarkan Tingkat Pendidikan}

Pada kelompok intervensi responden terbanyak berpendidikan perguruan tinggi yaitu sebanyak 11 orang $(68,8 \%)$, sedangkan pada kelompok kontrol responden terbanyak berpendidikan SMA yaitu sebanyak 9 orang $(56,3 \%)$. 


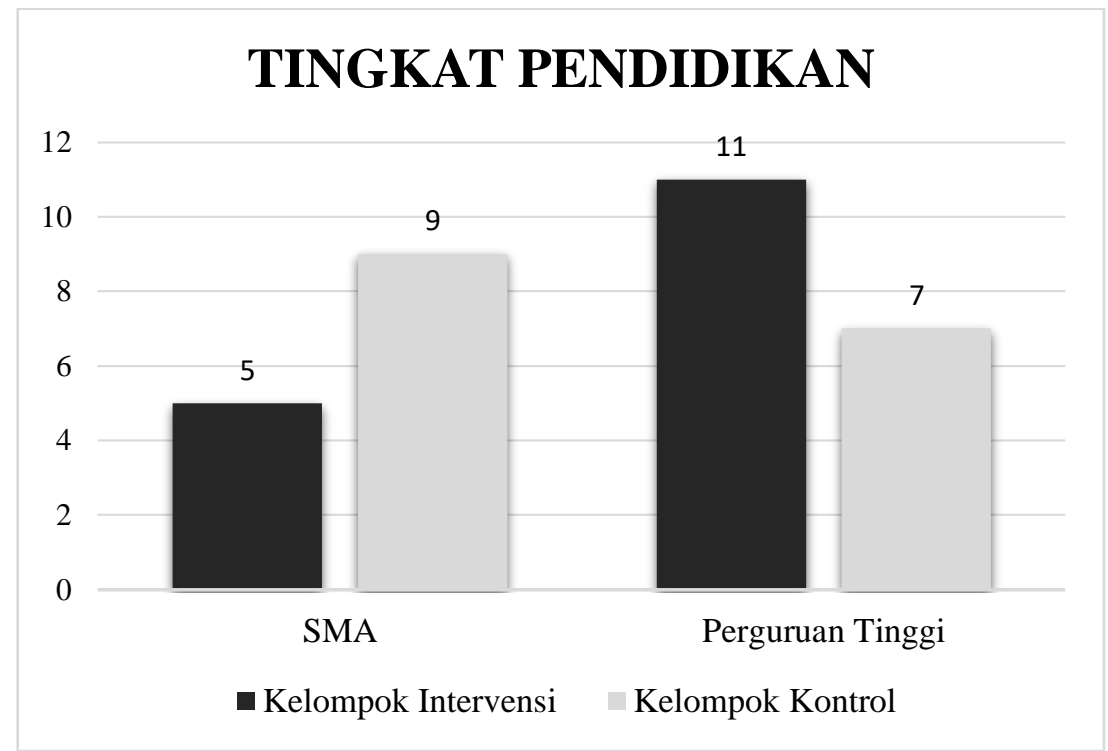

Gambar 2. Distribusi Responden Berdasarkan Tingkat Pendidikan

\section{Distribusi Responden Berdasarkan Riwayat Paritas}

Pada kelompok intervensi sebanyak 9 orang $(56,3 \%)$ merupakan primigravida, sedangkan pada kelompok kontrol sebanyak 10 orang $(62,5 \%)$ merupakan multigravida.

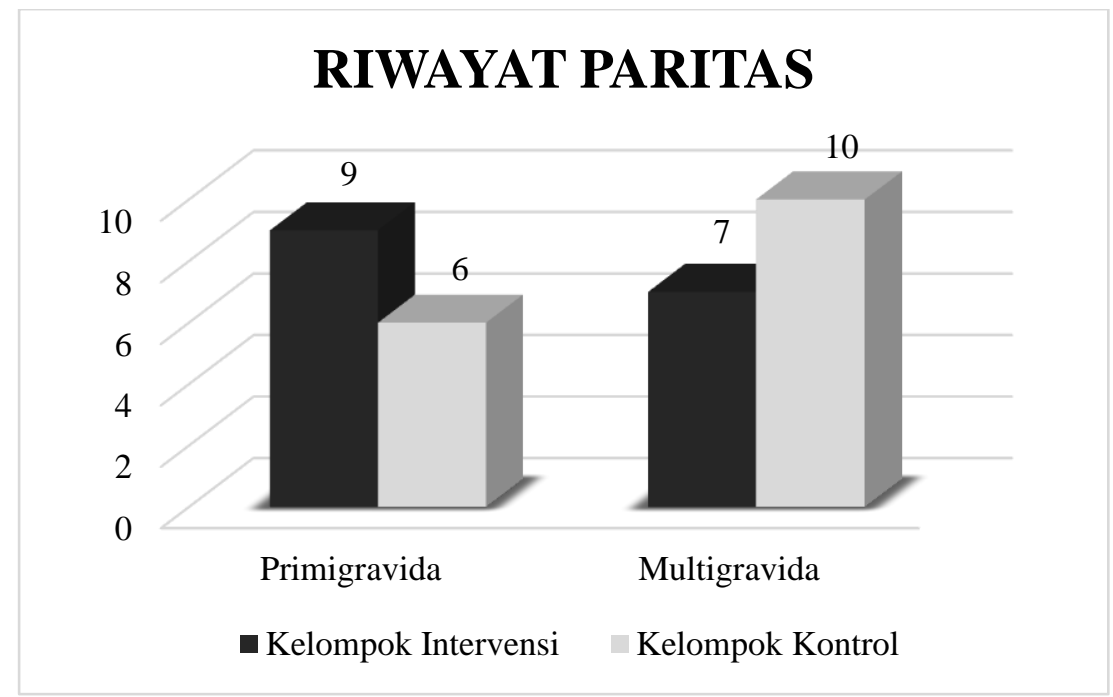

Gambar 3. Distribusi Responden Berdasarkan Riwayat Paritas

\section{Distribusi Responden Berdasarkan Tingkat Kecemasan}

Pada hasil pretest kelompok intervensi didapatkan 6 orang $(37,5 \%)$ tidak mengalami kecemasan, 7 orang $(43,8 \%)$ dengan tingkat kecemasan ringan dan 3 orang $(18,8 \%)$ dengan tingkat kecemasan sedang, sedangkan pada kelompok kontrol sebanyak 5 orang $(31,3 \%)$ tidak mengalami kecemasan, 5 orang $(31,3 \%)$ memiliki kecemasan 
Jurnal Kebidanan Mutiara Mahakam, Vol 8, No 1, Tahun 2020, Hal 8-20

ringan, 5 orang $(31,3 \%)$ dengan kecemasan sedang, dan 1 orang $(6,3 \%)$ dengan kecemasan berat.

Pada hasil posttest didapatkan pada kelompok intervensi sebanyak 15 orang $(93,8$ $\%)$ tidak mengalami kecemasan dan 1 orang $(6,3 \%)$ dengan kecemasn ringan, sedangkan pada kelompok kontrol didapatkan 5 orang $(31,3 \%)$ tidak mengalami kecemasan, 7 orang $(43,8 \%)$ dengan kecemasan ringan, dan 4 orang (25\%) dengan kecemasan sedang.

Tabel 1. Distribusi Responden Berdasarkan Tingkat Kecemasan

\begin{tabular}{ccccc}
\hline \multirow{2}{*}{$\begin{array}{c}\text { Tingkat } \\
\text { Kecemasan }\end{array}$} & \multicolumn{2}{c}{ Kelompok } & \multicolumn{2}{c}{$\begin{array}{c}\text { Kelompok } \\
\text { Kntervensi }\end{array}$} \\
\cline { 2 - 5 } & Pre & Post & Pre & Post \\
\hline Tidak Ada & $6(37,5 \%)$ & $15(93,8 \%)$ & $5(31,3 \%)$ & $5(31,3 \%)$ \\
Ringan & $7(43,8 \%)$ & $1(6,3 \%)$ & $5(31,3 \%)$ & $7(43,8 \%)$ \\
Sedang & $3(18,8 \%)$ & 0 & $5(31,3 \%)$ & $4(25,0 \%)$ \\
Berat & 0 & 0 & $1(6,3 \%)$ & 0 \\
\hline Total & 16 & 16 & 16 & 16 \\
\hline
\end{tabular}

\section{Distribusi Responden Berdasarkan Kualitas Tidur}

Pada hasil pretest kelompok intervensi didapatkan sebanyak 6 orang $(37,5 \%)$ memiliki kualitas tidur baik, dan 10 orang $(62,5 \%)$ dengan kualitas tidur buruk, sedangkan pada kelompok kontrol didapatkan 2 orang $(18,8 \%)$ memiliki kualitas tidur baik, dan 14 orang $(81,3 \%)$ memiliki kualitas tidur buruk.

Setelah dilakukan intervensi, pada kedua kelompok dilakukan posttest dan didapatkan hasil pada kelompok intervensi 16 orang (100\%) memiliki kualitas tidur baik, sedangkan pada kelompok kontrol didapatkan 4 orang $(25,0 \%)$ memiliki kualitas tidur baik, dan 12 orang $(75,0 \%)$ memiliki kualitas tidur buruk.

Tabel 2. Distribusi Responden Berdasarkan Kualitas Tidur

\begin{tabular}{ccccc}
\hline \multirow{2}{*}{$\begin{array}{c}\text { Kualitas } \\
\text { Tidur }\end{array}$} & \multicolumn{2}{c}{$\begin{array}{c}\text { Kelompok } \\
\text { Intervensi }\end{array}$} & \multicolumn{2}{c}{$\begin{array}{c}\text { Kelompok } \\
\text { Kontrol }\end{array}$} \\
\cline { 2 - 5 } & Pre & Post & Pre & Post \\
\hline Baik & $6(37,5 \%)$ & $16(100,0 \%)$ & $2(12,5 \%)$ & $4(25,0 \%)$ \\
Buruk & $10(62,5 \%)$ & 0 & $14(87,5 \%)$ & $12(75,0 \%)$ \\
\hline Total & 16 & 16 & 16 & 16 \\
\hline
\end{tabular}

\section{Analisis Perbedaan Tingkat Kecemasan Antara Sebelum dan Sesudah Prenatal Yoga}

Berdasarkan analisis statistik menggunakan uji Wilcoxon didapatkan nilai $\mathrm{P}=$ 0,001 pada kelompok intervensi dan nilai $\mathrm{P}=0.825$ pada kelompok kontrol. Nilai $\mathrm{P}$ pada kelompok intervensi lebih kecil dari 0,05 $(\mathrm{P}<0,05)$. Dengan hasil tersebut dapat ditarik 
kesimpulan bahwa terdapat perbaikan tingkat kecemasan antara sebelum dan sesudah prenatal yoga.

Tabel 3. Analisis Perbedaan Tingkat Kecemasan Antara Sebelum dan Sesudah Prenatal

\begin{tabular}{|c|c|c|c|c|}
\hline \multicolumn{5}{|c|}{ Yoga } \\
\hline \multirow{2}{*}{$\begin{array}{c}\text { Tingkat } \\
\text { Kecemasan }\end{array}$} & \multicolumn{2}{|c|}{$\begin{array}{l}\text { Kelompok } \\
\text { Intervensi }\end{array}$} & \multicolumn{2}{|c|}{$\begin{array}{c}\text { Kelompok } \\
\text { Kontrol }\end{array}$} \\
\hline & Pre & Post & Pre & Post \\
\hline Median & 14,5 & 6,5 & 16,81 & 16,19 \\
\hline $\begin{array}{l}\text { Minimum - } \\
\text { Maksimum }\end{array}$ & $3-24$ & $0-14$ & $4-29$ & $5-27$ \\
\hline Nilai P & \multicolumn{2}{|c|}{0,001} & \multicolumn{2}{|c|}{0,825} \\
\hline
\end{tabular}

Pada Tabel 3 didapatkkan hasil uji pada kelompok intervensi adalah $\mathrm{P}=0,001$ dan pada kelompok kontrol adalah $\mathrm{P}=0,825$, dapat disimpulkan adanya perbedaan tingkat kecemasan pada kelompok intervensi dibandingkan pada kelompok kontrol. Sehingga menunjukkan prenatal yoga efektif dalam mengurangi tingkat kecemasan.

Kecemasan adalah gangguan yang ditandai dengan perasaan ketakutan atau kekhawatiran yang mendalam dan berkelanjutan, tidak mengalami gangguan dalam menilai realitas, kepribadian masih tetap utuh, perilaku dapat terganggu tetapi masih dalam batas normal (Hawari, dikutip dalam Fazdria, dkk, 2016). Pada ibu hamil khususnya trimester III perubahan psikologi ibu terkesan lebih kompleks dan meningkat dibandingkan trimester sebelumnya, dan ini tidak lain dikarenakan kondisi kehamilan yang semakin membesar (Janiwarty \& Pieter, 2013).

Jiang, dkk (2015) dalam penelitiannya menyatakan bahwa yoga lebih efektif daripada berjalan atau latihan standar prenatal. Yoga menunjukkan dapat menurunkan kejadian gangguan prenatal, kelahiran prematur, rasa nyeri dan stres serta meningkatkan hubungan interpersonal. Hasil ini juga sejalan dengan penelitian yang sebelumnya dilakukan oleh Hariyanto (2015) yang menyatakan bahwa terdapat perbedaan tingkat kecemasan ibu hamil antara sebelum dan sesudah prenatal yoga.

Prenatal yoga terdiri dari beberapa komponen antara lain latihan fisik (asana), latihan pernafasan (pranayama), dan meditasi (dhyana). Latihan fisik pada yoga dapat meningkatkan kekuatan fisik, fleksibilitas otot dan daya tahan tubuh, serta mempengaruhi kelenjar endokrin untuk menekan pengeluaran hormon stres dan meningkatkan sekresi hormon relaksan, sehingga menimbulkan kestabilan emosi dan mengurangi efek ketegangan. Pada pranayama dilakukan latihan pernapasan secara perlahan dan mendalam untuk menyiapkan pernafasan saat proses persalinan, sehingga ibu tetap tenang dan suplai oksigen ke janin tetap adekuat. Selain itu latihan ini merupakan pengalihan 
konsentrasi ibu dari nyeri persalinan. Pada meditasi dilakukan latihan relaksasi yang mendalam untuk mencapai keadaan relaksasi yang lebih maksimal (Husin, 2013). Seiring dengan penurunan tingkat hormon penyebab stres, maka seluruh badan mulai berfungsi pada tingkat lebih sehat dengan lebih banyak energi untuk penyembuhan (healing), penguatan (restoration), dan peremajaan (rejuvenation). Dengan demikian, ibu hamil akan merasa rileks seiring dengan menurunnya gejala kecemasan (Domin, dikutip dalam Dewi, dkk, 2017).

\section{Analisis Perbedaan Kualitas Tidur Antara Sebelum dan Sesudah Prenatal Yoga}

Berdasarkan analisis menggunakan uji statistik Wilcoxon didapatkan nilai $\mathrm{P}=$ 0,000 pada kelompok intervensi dan nilai $\mathrm{P}=0,348$ pada kelompok kontrol. Nilai $\mathrm{P}$ pada kelompok intervensi lebih kecil dari 0,05 $(\mathrm{P}<0,05)$. Dengan hasil tersebut dapat ditarik kesimpulan bahwa terdapat peningkatan kualitas tidur antara sebelum dan sesudah prenatal yoga.

Tabel 4. Analisis Perbedaan Kualitas Tidur Antara Sebelum dan Sesudah Prenatal Yoga

\begin{tabular}{ccccc}
\hline \multirow{2}{*}{$\begin{array}{c}\text { Kualitas } \\
\text { Tidur }\end{array}$} & \multicolumn{2}{c}{$\begin{array}{c}\text { Kelompok } \\
\text { Intervensi }\end{array}$} & \multicolumn{2}{c}{$\begin{array}{c}\text { Kelompok } \\
\text { Kontrol }\end{array}$} \\
\cline { 2 - 6 } & Pre & Post & Pre & Post \\
\hline Median & 6,19 & 3,13 & 7,62 & 7,13 \\
Minimum - & $4-10$ & $2-4$ & $3-13$ & $3-13$ \\
Maksimum & & 2000 & & 0,348 \\
\hline Nilai P & \multicolumn{2}{c}{0,000} \\
\hline
\end{tabular}

Hasil pengujian perbedaan nilai kualitas tidur pada kelompok intervensi dan kelompok kontrol adalah $\mathrm{P}=0,000$ dan $\mathrm{P}=0,348$, sehingga dapat disimpulkan bahwa terdapat perbedaan yang bermakna pada kelompok intervensi karena nilai $\mathrm{P}<0,05$. Hal ini relevan dengan penelitian yang dilakukan oleh Hannatuzzahro (2016) yang menyatakan bahwa terdapat perbedaan kualitas tidur ibu hamil sebelum dan sesudah senam yoga.

Pada penelitian ini didapatkan gangguan tidur yang dikeluhkan responden yaitu seringnya bangun pada tengah malam untuk buang air kecil atau merasa tidak nyaman saat tidur yang menyebabkan durasi tidur menjadi berkurang. Menurut Pillitteri (dalam Marwiyah, dkk, 2018), hal ini dapat dikarenakan oleh pertumbuhan janin dan pergerakan janin yang dapat menekan kandung kemih sehingga dapat meningkatkan frekuensi buang air kecil, beban tubuh yang semakin berat sehingga dapat merubah struktur tulang belakang sehingga ibu hamil dapat merasakan ketidaknyamanan di daerah pinggang. 
Kondisi ini juga dapat menimbulkan perubahan psikologis ibu hamil, yang terkadang perubahan fisik yang dialaminya dapat menimbulkan kecemasan, dan kekhawatiran saat menghadapi persalinan, hal ini yang terkadang dapat mempengaruhi kualitas tidur ibu hamil.

Latihan - latihan pada prenatal yoga dapat menguatkan sistem pernapasan, menenangkan sistem saraf, membantu mengurangi dan menghilangkan kekacauan, dan dapat menguatkan sistem kekebalan tubuh. Gerakan yoga dapat membantu penderita insomnia untuk dapat tidur dengan nyenyak karena dapat memberikan pengaruh positif pada pusat saraf otak yang akan melepaskan rasa kaku pada otot di tubuh dan memberikan ketenangan pikiran dan pada akhirnya membantu untuk tidur (Shindu, 2013). Menurut Rahma (2014), senam yoga dapat mengurangi gangguan tidur pada ibu hamil trimester III karena gerakan yoga menekankan pada pernapasan, meditasi, rileksasi yang akan membuat tubuh menjadi lentur terutama pada otot - otot jalan lahir, sehingga pada senam yoga dapat meningkatkan kualitas tidur yang baik karena pengaruh neurotransmitter endorfin meningkat yang akan membuat ibu hamil merasa nyaman dan rileks. Olah napas senam yoga juga membuat otot - otot lebih rileks, pikiran lebih tenang, tubuh lebih segar, dan meningkatkan kemampuan berkonsentrasi yang semuanya berpengaruh terhadap kenyenyakan tidur.

\section{Analisis Hubungan Prenatal Yoga Terhadap Tingkat Kecemasan}

Kategori pada tingkat kecemasan disederhanakan hanya menjadi dua kategori yaitu ada kecemasan dan tidak ada kecemasan, dikarenakan terdapat beberapa sel dengan nilai expected count kurang dari 5. Berdasarkan analisis menggunakan uji statistik ChiSquare didapatkan nilai $\mathrm{P}=0,001$. Nilai $\mathrm{P}$ lebih kecil dari 0,05 $(\mathrm{P}<0,05)$. Dengan hasil tersebut dapat ditarik kesimpulan bahwa prenatal yoga berhubungan terhadap tingkat kecemasan.

Tabel 5. Analisis Hubungan Prenatal Yoga Terhadap Tingkat Kecemasan

\begin{tabular}{|c|c|c|c|c|c|c|c|}
\hline \multirow{3}{*}{$\begin{array}{l}\text { Keikutsertaan } \\
\text { Prenatal Yoga }\end{array}$} & \multicolumn{4}{|c|}{ Kecemasan } & \multirow{2}{*}{\multicolumn{2}{|c|}{ Total }} & \multirow{3}{*}{ Nilai P } \\
\hline & \multicolumn{2}{|c|}{ Ada } & \multicolumn{2}{|c|}{ Tidak Ada } & & & \\
\hline & $\mathrm{N}$ & $\%$ & $\mathrm{~N}$ & $\%$ & $\mathrm{~N}$ & $\%$ & \\
\hline Ikut & 1 & 6,3 & 15 & 93,8 & 16 & 100 & \multirow{3}{*}{0,001} \\
\hline Tidak Ikut & 11 & 68,8 & 5 & 31,3 & 16 & 100 & \\
\hline Total & 11 & 34,4 & 21 & 65,6 & 32 & 100 & \\
\hline
\end{tabular}




\section{Analisis Hubungan Prenatal Yoga Terhadap Kualitas Tidur}

Berdasarkan analisis menggunakan uji Chi - Square didapatkan nilai $\mathrm{P}=0,000$. Nilai P lebih kecil dari 0,05 ( $<<0,05)$. Dengan hasil tersebut dapat ditarik kesimpulan bahwa prenatal yoga berhubungan dengan kualitas tidur.

Tabel 6. Analisis Hubungan Prenatal Yoga Terhadap Kualitas Tidur

\begin{tabular}{|c|c|c|c|c|c|c|c|}
\hline \multirow{3}{*}{$\begin{array}{l}\text { Keikutsertaan } \\
\text { Prenatal Yoga }\end{array}$} & \multicolumn{4}{|c|}{ Kualitas Tidur } & \multirow{2}{*}{\multicolumn{2}{|c|}{ Total }} & \multirow{3}{*}{ Nilai $P$} \\
\hline & \multicolumn{2}{|c|}{ Baik } & \multicolumn{2}{|c|}{ Buruk } & & & \\
\hline & $\mathrm{N}$ & $\%$ & $\mathrm{~N}$ & $\%$ & $\mathrm{~N}$ & $\%$ & \\
\hline Ikut & 16 & 100 & 0 & 0 & 16 & 100 & \\
\hline Tidak Ikut & 4 & 25 & 12 & 75 & 16 & 100 & 0,000 \\
\hline Total & 20 & 62,5 & 12 & 37,5 & 32 & 100 & \\
\hline
\end{tabular}

Pada Tabel 5 dan Tabel 6 didapatkan hasil uji analisis hubungan prenatal yoga dengan tingkat kecemasan adalah $\mathrm{P}=0,001$ dan hasil uji hubungan prenatal yoga dengan kualitas tidur adalah $\mathrm{P}=0,000$, dimana nilai $\mathrm{P}$ pada kedua variabel adalah $<0,05$, sehingga dapat disimpulkan bahwa prenatal yoga berhubungan dengan tingkat kecemasan dan kualitas tidur. Prenatal yoga merupakan salah satu cara yang baik untuk mempersiapkan persalinan yang dilakukan di kelas prenatal, karena dalam kelas ini latihan disesuaikan dengan kondisi ibu hamil dengan berbagai pendekatan latihan seperti peregangan, konsentrasi dan pengaturan pernapasan yang memiliki banyak manfaat bagi ibu hamil dan janinnya seperti mengurangi stress dan kecemasan, meningkatkan kualitas tidur, meningkatkan kekuatan, fleksibilitas dan daya tahan yang diperlukan untuk persalinan, penurunan akibat sakit punggung bagian bawah, mual, sakit kepala dan sesak nafas serta penurunan resiko persalinan prematur, hipertensi pada kehamilan dan gangguan pertumbuhan janin (Wiadnyana, dikutip dalam Rahma, 2014).

Menurut Hartasih, dkk (2018), prenatal yoga memberikan banyak manfaat yang membuat ibu hamil lebih rileks, ketenangan pikiran, mengetahui teknik pernafasan yang benar, serta memfokuskan perhatian pada ritme pernafasan dimana semua manfaat tersebut akan memudahkan ibu dalam proses persalinan. Sedangkan ibu hamil yang tidak melakukan prenatal yoga akan kurang pengetahuan mengenai cara mengontrol pikiran serta pengolahan nafas yang benar dalam proses persalinan. Penilitian yang dilakukan oleh Hamdiah, dkk (2017), menyatakan bahwa semakin sering ibu hamil mengikuti yoga maka akan semakin mengurangi tingkat kecemasan, dikarenakan pada latihan - latihan yoga dapat mengurangi kinerja hipotalamus untuk melepaskan neuropeptida yang selanjutnya akan merangsang kelenjar hipofisis untuk melepaskan ACTH (Adrenocorticotropic hormone), yang kemudian menekan produksi kortisol. Dengan 
menurunnya kadar kortisol menyebabkan gejala kecemasan yang dirasakan menjadi berkurang.

\section{SIMPULAN}

Berdasarkan hasil penelitian dan pembahasan, dapat disimpulkan bahwa terdapat perbedaan tingkat kecemasan dan kualitas tidur antara sebelum dan sesudah prenatal yoga, dan terdapat hubungan antara prenatal yoga dengan tingkat kecemasan dan kualitas tidur pada ibu hamil trimester III.

\section{DAFTAR PUSTAKA}

ADAA. (2015, Juli). Pregnancy and Medication. Retrieved Januari 21, 2019, from Anxiety and Depression Association of America: https://adaa.org/living-withanxiety/women/pregnancy-and-medication

Annisa, D., \& Ifdil. (2016). Konsep Kecemasan (Anxiety) pada Lanjut Usia (Lansia). Konselor, 5.

Dewi, E., Suwondo, A., \& Wahyuni, S. (2017). Pengaruh Kombinasi Yoga Prenatal dan Senam Hamil Terhadap Perubahan Kadar Kortisol dan Lama Persalinan Kala I. Tunas - Tunas Riset Kesehatan, VII.

Difarissa, R., Tarigan, J., \& Hadi, D. (2016). Hubungan Tingkat Kecemasan dan Lama Partus Kala I Fase Aktif pada Primigravida di Pontianak. Jurnal Cerebellum.

Fazdria, \& Harahap, M. (2016). Gambaran Tingkat Kecemasan Pada Ibu Hamil Dalam Menghadapi Persalinan di Desa Tualang Teungoh Kecamatan Langsa Kota Kabupaten Kota Langsa Tahun 2014. Jurnal Kedokteran Syiah Kuala, XVI(1), 613.

Hamdiah, Suwondo, A., Hardjanti, T., Soejoenes, A., \& Anwar, M. (2017). Effect of Prenatal Yoga on Anxiety, Blood Pressure, and Fetal Heart Rate in Primigravida Mothers. Belitung Nursing Journal, Belitung.

Hannatuzzahro, S., Susilo, E., \& Sofiyanti, I. (2016). Perbedaan Kualitas Tidur Ibu Hamil Usia Kehamilan 30-35 Minggu Sebelum dan Sesudah Senam Yoga di RB " $N W$ " Ungaran. Skripsi, Stikes Ngudi Waluyo, Program Studi Kebidanan, Ungaran.

Hariyanto, M. (2015). Pengaruh Senam Yoga Terhadap Tingkat Kecemasan Ibu Hamil Trimester III di Praktik Bidan Mandiri Kabupaten Boyolali. Skripsi, Universitas Muhamadiyah Surakarta, Fakultas Ilmu Kesehatan, Boyolali. 
Jurnal Kebidanan Mutiara Mahakam, Vol 8, No 1, Tahun 2020, Hal 8-20

Hartasih, A., Mastryagung, G., \& Nuryanto, I. (2018). Perbedaan Tingkat Kecemasan Ibu Hamil Yang Melakukan Dengan Yang Tidak Melakukan Prental Yoga Di Klinik Bumi Sehat Tahun 2018. Skripsi, Sekolah Tinggi Ilmu Kesehatan Bali, Bali.

Husin, F. (2013). Asuhan Kehamilan Berbasis Bukti. Jakarta: Sagung Seto.

Jamalzehi, A., Omeidi, K., Javadi, M., \& Dashipour, A. (2017). Evaluation of Sleep Quality in Third Trimester of Pregnancy and Its Relation to Birth Characteristics in Women Referred to Gynecology Clinic of Tamin Ejtemaee Hospital of Zahedan. Der Pharmacia Lettre, 194-201.

Janiwarty, B., \& Pieter, H. (2013). Pendidikan Psikologi Untuk Bidan. Yogyakarta: Rapha Publishing.

Jiang, Q., Wu, Z., Zhou, L., \& Chen, P. (2015). Effects of Yoga Intervention During Pregnancy: a Review for Current Status. American Journal of Perinatology, XXXII(6).

Komalasari, D., Maryati, I., \& Koeryaman, M. (2012). Hubungan Antara Tingkat Kecemasan Dengan Kualitas Tidur Pada Ibu Hamil Trimester III di Puskesmas Jatinangor Kabupaten Sumedang. eJorunal Mahasiswa Universitas Padjajaran, 1 .

Krisnadi, S. (2010). Sinopsis Yoga untuk kehamilan: sehat, bahagia dan penuh makna.

Larasati, P., \& Wibowo, A. (2012). Pengaruh Keikutsertaan Senam Hamil Terhadap Kecemasan Primigravida Trimester Ketiga dalam Menghadapi Persalinan. Skripsi, Universitas Airlangga, Fakultas Kesehatan Masyarakat, Surabaya.

Marwiyah, N., \& Sufi, F. (2018). Pengaruh Senam Hamil Terhadap Kualitas Tidur Ibu Hamil Trimester II dan III di Kelurahan Margaluyu Wilayah Kerja Puskesmas Kasemen. Faletehan Health Journal, V(3), 123-128.

National Sleep Foundation. (2006, Februari). Pregnancy and Sleep. Retrieved Maret 24, 2019, from National Sleep Foundation: https://www.sleepfoundation.org/articles/pregnancy-and-sleep

Pratignyo, T. (2014). Yoga Ibu Hamil. Jakarta: Pustaka Bunda.

Rahma, F. (2014). Hubungan Senam Yoga Terhadap Peningkatan Kualitas Tidur Pada Ibu Hamil Trimester III. Skripsi, Universitas Muhammadiyah Surakarta, Fakultas Ilmu Kesehatan, Surakarta.

Robin, G. (2015). Hubungan Tingkat Kecemasan dengan Kualitas Tidur Pada Ibu Hamil Primigravida Trimester III di Puskesmas Sidorejo Lampung Timur Tahun 2015. Jurnal Program Studi Ilmu Keperawatan, Universitas Malahayati. 
Jurnal Kebidanan Mutiara Mahakam, Vol 8, No 1, Tahun 2020, Hal 8-20

Sarifah, S. (2016). Hubungan Kecerdasan Emosi dengan Kecemasan Ibu Hamil Pertama Trimester ke III dalam Menghadapi Persalinan di Samarinda. eJournal Psikologi Fisip Unmul, 373-385.

Shindu, P. (2013). Yoga Untuk Hidup Sehat. Bandung: Mizan Pustaka.

Wahyuningsih, M. (2010). Insidensi Partus Lama pada Primipara dan Multipara di RSUD Dr. Moewardi Surakarta Tahun 2009. Skripsi, Universitas Muhammadiyah Surakarta, Fakultas Kedokteran, Surakarta. 